\title{
Preface 1939
}

California has so great a diversity of places and people and things that the problem of getting it between the covers of a single book seemed almost unsolvable. The final preparation of this guide has involved the difficult task of choosing between what to put in and what to leave out. The staff of the Federal Writers' Project in California knows that its own trials in gathering, checking and rechecking, assembling, and selecting the thousands of items that go into the making of a guide book have been shared by the editors of the forty-seven other State books in the American Guide Series. But in the course of eliminating more words than there are in these pages, the California staff has sometimes wished that its State were just a little smaller, so that it might be described in more detail.

And yet there is more in this book than the editors thought it could possibly include; for, although the distance between the borders of Oregon and Mexico is more miles than they like to think about, they have covered every mile. The book, moreover, has been written to be read, not only by those to whom California is still an unseen and fabulous land of sunshine and oranges, but also by those who will look in these pages for something new and little-known about the everyday California in which they live and work. For readers of both kinds, visitors and residents, the editors have tried to make this book a true mirror of the State and its people. Romance has been kept in its place - Joaquin Murrieta does not jump out from behind every tree or boulder in California to hold up travelers, and yet he does pop up often enough that the observant reader will have little trouble finding him.

The editors wish to acknowledge their indebtedness to the work of others who have preceded them in describing California, and especially to California, an Intimate Guide by Aubrey Drury, Rider's California; $A$ Guidebook for Travelers by Fremont Rider, and Historic Spots in California by H. E. and E. G. Rensch and Mildred Brooke Hoover.

The California staff gratefully acknowledges the aid of Federal, State, and local governmental agencies, and of commercial and civic associations and automobile clubs. Particular appreciation is due the staffs of the Bancroft and State Libraries, for their cooperation. 
XXX PREFACE TO THE I 939 EDITION

Among the many individuals to whom the editors wish to express their gratitude for generous aid in special fields are: Herbert E. Bolton, Will G. Corlett, Richard Down, Alfred Frankenstein, Louis J. Gill, Florence Hagee, Norman E. A. Hinds, Paul Robinson Hunter, Rupert Hughes, Olaf Jenkins, William Templeton Johnson, Idwal Jones, William Knowles, R. B. Koeber, A. L. Kroeber, Grace L. McCann Morely, Richard S. Requa, C. J. Ryland, Carl Sauer, Windsor Soule, W. L. Stephenson, George R. Stewart, Jr., Hilmuth Ulmer, T. K. Whipple, Lloyd Yoder, and finally the sponsor, Mabel R. Gillis, State Librarian, for her interest and gracious advice.

Field supervision from the Washington office of the Federal Writers' Project was done by Clair Laning, Assistant National Director.

James Hopper, State Director for Northern California Leon Dorais, State Director for Southern California 